\title{
Sustaining benefits of nutritional therapy in young adults with Phenylketonuria - A 2 year Prospective Study
}

Johannes Krämer ( $\boldsymbol{\nabla}$ j.kraemer@mail.de )

\section{Research}

Keywords: Metabolism, Phenylketonuria, Micronutrients, Nutritional Therapy, Phenylalanine

Posted Date: January 15th, 2020

DOI: https://doi.org/10.21203/rs.2.20940/v1

License: (c) (i) This work is licensed under a Creative Commons Attribution 4.0 International License.

Read Full License

Version of Record: A version of this preprint was published at Molecular Genetics and Metabolism Reports on March 1st, 2020. See the published version at https://doi.org/10.1016/j.ymgmr.2020.100573.

\section{EDITORIAL NOTE:}

24 January 2022: The published version of this preprint was retracted from Molecular Genetics and Metabolism Reports on 6 April 2021. The retraction notice can be found here. Research Square has withdrawn this preprint. 


\section{Abstract}

Introduction. Phenylketonuria (PKU) is an inborn error of metabolism, which is caused by a deficiency in the enzyme phenylalanine hydroxylase (PAH). Life-long Phe-free diet impairs quality of life, especially in adolescents and young adults which take responsibility over their diet and therapy from their parents, but expect freedom in daily routine.

Methods and Results. 105 patients with PKU were screened for eligibility for participating in this study. data of 21 patients with GPV $\leq 5$ and age between 14 and 30 years were included in the analysis. Mean age of the study population was $22.6 \pm 7.5$ years, 8 patients (38\%) were female. At baseline, structured counselling by a professional nutrionist was performed. Follow-up visits were performed after $6.5 \pm 3.9$, $11.2 \pm 3.3,19.8 \pm 7.4$ and $25.5 \pm 5.7$ months.

Mean Phe-level at baseline was $926 \pm 432 \mu \mathrm{mol} / \mathrm{l}$, after six months Phe-levels were significantly reduced to $709 \pm 314 \mu \mathrm{mol} / \mathrm{l}(\mathrm{p}=0.039)$, in total 4 additional patients ( $38 \%$ of the population) reached values within the therapeutic goal. After 12, 18 and 24 months, mean Phe-level elevated significantly back to initial level $(869 \pm 427 \mu \mathrm{mol} / \mathrm{l} ; \mathrm{p}=0.311)$. Mean daily intake of natural protein at baseline was $32.3 \pm 24.3 \mathrm{~g}$ per day. There was a significant decrease after 6 months $(26.9 \pm 18.8 \mathrm{~g} /$ day; $p=0.049)$ and 12 months $(25.9 \pm 16.2$ $\mathrm{g} /$ day; $\mathrm{p}=0.30)$ compared to baseline. Values at 18 months $(27.5 \pm 9.2 \mathrm{~g} /$ day; $\mathrm{p}=0.26)$ and 24 months $(35.0 \pm 22.3 \mathrm{~g} /$ day; $\mathrm{p}=0.87)$ did not differ. Mean daily supplementation of Phe-free amino acids was $26.2 \pm 19.2 \mathrm{~g}$ per day. In all follow-up examinations a significant increase compared to baseline values was calculated ( $42.4 \pm 17.6 \mathrm{~g} /$ day after 6 moths $(p=0.028), 52.1 \pm 29.9 \mathrm{~g} /$ day after 12 months $(p=<0.01)$, $38.7 \pm 20.3 \mathrm{~g} /$ day after 18 months $(p<0.01)$ and $39.3 \pm 21.9 \mathrm{~g} /$ day after 24 months $(\mathrm{p}=0.014)$ ). At baseline, mean total protein intake (natural protein plus supplements) was $0.97 \pm 0.42 \mathrm{~g}$ per kg body weight $(\mathrm{g} / \mathrm{kgBW})$. After 24 months the protein intake was within recommended levels. $(1.23 \pm 0.33 \mathrm{~g} / \mathrm{kgKB}$; $\mathrm{p}=0.013$ ). After 24 months, plasma Vitamin B12 increased to $424.8 \pm 176.9 \mathrm{pg} / \mathrm{ml}$ (baseline $368.6 \pm 205.6$ $\mathrm{pg} / \mathrm{ml} ; \mathrm{p}=0.049$ ) and Vitamin $\mathrm{D}$ increased to $30.4 \pm 9.9 \mathrm{ng} / \mathrm{ml}$ (baseline $24.5 \pm 10.1 \mathrm{ng} / \mathrm{ml} ; \mathrm{p}=0.06$ ).

Conclusion. Counselling by a professional nutrionist in young adults with PKU has clear short-term effects on plasma Phe-levels. Easy applicable therapeutic recommendations, as additional intake of amino acid supplement, are well tolerated and result in strict therapy adherence up to 24 months. Apart from that, the effects on Phe-levels seem only to sustain for about 6 months. More frequent nutritional counselling, i.e. at least two times per year, is recommended to preserve positive effects on Phe-levels. Lack of Vitamin B12 and Vitamin D still are common in PKU patients, but not necessarily need to be substituted. They can effectively be equalized by a well-balanced diet within 24 months.

\section{Introduction}

Phenylketonuria (PKU) is an inborn error of metabolism, which is caused by a deficiency in the enzyme phenylalanine hydroxylase (PAH), resulting in disturbances of phenylalanine (Phe) metabolism. [[i]] The elevated Phe concentrations in adult patients affect neurophysical functions, resulting in cognitive 
impairment and neuropsychiatric symptoms linked to amount of the elevation [[ii], [iii]] as well as neurological symptoms [[iv]]. The life-long treatment should result in blood Phe-levels of $120-360 \mu \mathrm{mol} / /$ [[v], [vi]]. Life-long diet impairs quality of life, especially in adolescents and young adults who took responsibility over their diet and therapy from their parents, but expect freedom in daily routine. This is visible in loosen therapy adherence and therefore higher plasma Phe-levels in these patients. According to clinical experience, the treatment of PKU in young adults is often challenging and results in Phe levels far above the recommendations.

Treatment options are protein-restricted diet combined with Phe-free medical foods and amino acid mixtures (AAM) respectively the use of saproterin dihydrochloride (Kuvan ${ }^{\circledR}$, BioMarin Pharmaceutical Inc., Novato, California, USA) which is an effective treatment in patients with residual PAH activity [[vii], [viii]]. Pegvaliase (Palynziq ${ }^{\circledR}$, BioMarin Pharmaceutical Inc., Novato, California, USA) is a novel enzyme substitution therapy approved by the European Drug Administration (EDA) in May 2019 for the treatment of PKU in adults and children $\geq 16$ years of age [[ix], [x]]. The selection of the right patient for a potential harmful treatment is essential for patient's contentedness and long-term therapy compliance and needs well-founded information for long-term effects of conservative treatment modalities. The individual Phe tolerance depends on residual phenylalanine hydroxylase activity [[xi]] and varies between patients. The necessary AAM dosage also depends on the individual Phe tolerance, age and body weight. To account for metabolic imbalances and potential absorption deficiencies of amino acids from the AAM, it is generally suggested to provide additional $20 \%$ of the recommended [[xii], [xiii]] protein supply. To avoid micronutrient deficiencies, as the patients' choice of natural food is extremely limited, the AAM contain significant amounts of vitamins, minerals and trace elements. Patients who follow a relaxed diet or lost therapy adherence take only a small amount or no AAM. Consequently, these patients might be at risk of insufficient micronutrient supply. Especially the supply with Vitamin B12 has been shown to be often far under recommendations [[xiv], [xv], [xvi]]. Due to several, in particular cultural, differences in relationship and treatment modalities, a selective observation of different countries is necessary to improve individual patient care.

Main objective of this study was to investigate the long-term effects (24 months) of an intervention by professional nutritionists on plasma Phe-levels, daily protein intake, use of AAM and micronutrient supply in this unsteady and challenging subgroup of PKU patients.

\section{Materials And Methods}

105 patients (childrens and adults) with disturbances of phenylalanine metabolism are in regular care of the metabolic centre of Ulm. All patients were screened for eligibility for participating in this study. Exclusion criteria were the following: all-time maximum Phe-levels $<600 \mu \mathrm{mol} / \mathrm{l}$, age $<14$ years or $>30 y e a r s$, current or planned pregnancy, no availability of genetic information or genetic predictive value 
$(G P V)>5$. Common cut-off-values for GPV were used as follows: 0.0-2.7 for classic PKU, 2.8-6.6 for mild PKU and 6.7-10.0 for mild hyperphenylalaninemia. Among the study population 42 patients were classified as eligible for participation and were invited to a regular consultation in our clinic. All patients suffered from PKU and had dietary treatment in their whole childhood with Phe levels lower than $360 \mu \mathrm{mol} / \mathrm{l}$ in the first 10 years of their live (ECTPKU). 27 patients were willing to participate, 2 patients were excluded due to personal circumstances. Within the regular routine assessment, we collected data about daily Phe-and protein-intake (analysis of 3-day protocols) and clinical data. Retrospective data about protein intake were assessed out of clinical records. We performed routine clinical and neurological examination and collected blood samples for determination of plasma Phe-levels in our own lab (highpressure liquid chromatography, Biochrom 30+, Harvard Bioscience Inc., Holliston, Massachusetts, USA) as well as determination of vitamins and micronutrients in plasma (plasma values of Vitamin C, Vitamin B12, Vitamin D, Vitamin E, plasma iron and zinc). Follow-Up assessments were arranged after $6,12,18$ and 24 months for acquiring information about daily Phe- and protein-intake (analysis of 3-day protocols) and clinical data at every appointment, as well as determination of plasma Phe-levels. Plasma levels of vitamins and micronutrients were re-assessed after 24 months. The study protocol is shown in figure 1.

All values are presented as the mean \pm SD or as the absolute number. Differences between two groups were tested using the paired or unpaired t-test if normal distribution could be assumed. Otherwise, the Wilcoxon rank-sum test was performed. For categorical data, the chi-squared test or the Fisher's exact test was used. All differences were tested two-sided. Larger numbers of groups were tested using two-way analysis of variance. P-values of 0.05 are considered as indicating statistical significance. Data were analyzed using SPSS version 25.0 (SPSS Inc., Chicago, IL, USA). Written informed consent was obtained by patients or their legal representatives.

\section{Results}

A total of 105 patients was screened for participating in this study. Main exclusion criteria were the following: Age not within the inclusion range or treatment with Saproterine $(n=58)$, not willing to participate $(n=15)$, no genetic information $(n=5)$ and personal circumstances avoiding regular follow-ups $(n=2)$. At least 25 patients were included in this study, of which 4 patients were lost to follow-up. In total, data of 21 patients were included in the analysis. Mean age of the study population was $22.6 \pm 7.5$ years, 8 patients (38\%) were female. Follow-up visits were performed after $6.5 \pm 3.9$ months (Follow-Up 1), 11.2 \pm 3.3 months (Follow-up 2), 19.8 \pm 7.4 months (Follow-Up 3) and 25.5 \pm 5.7 months (Final Visit) after the baseline examination. The study protocol is shown in figure 1. Mean plasma Phe-level at baseline was $957 \pm 389 \mu \mathrm{mol} / \mathrm{l}$, only 4 patients $(19 \%)$ reached the therapeutic goal (Phe $<600 \mu \mathrm{mol} / \mathrm{l})$. All baseline characteristics are presented in table 1. 


\section{Changes in plasma Phe-levels and daily protein-intake}

Retrospective data, according to plasma Phe-level $(930 \pm 414 \mu \mathrm{mol} / \mathrm{l} ; \mathrm{p}=0.69)$, daily Phe-Intake $(1530 \pm 1139$ $\mathrm{g} /$ day; $\mathrm{p}=0.89)$, daily intake of natural protein $(33.4 \pm 26.1 \mathrm{~g} / \mathrm{day} ; \mathrm{p}=0.78)$ and supplemental intake of Phefree amino acids $(23 \pm 15 \mathrm{~g} /$ day; $p=0.85)$ were not different to baseline values.

Mean Phe-level at baseline was $926 \pm 432 \mu \mathrm{mol} / \mathrm{l}$, only 4 patients $(19 \%)$ had values within the therapeutic goal. Six months after the intervention, Phe-levels were significantly reduced to $709 \pm 314 \mu \mathrm{mol} / /$ $(p=0.039)$, in total 4 additional patients (38\% of the population) reached values within the therapeutic goal. After 12 months, mean Phe-level elevated significantly to initial level $(901 \pm 398 \mu \mathrm{mol} / \mathrm{l}, \mathrm{p}=0.04 \mathrm{vs}$. Follow-up $1 ; p=0.187$ vs. baseline) and henceforth remained stable after 18 months $(919 \pm 306 \mu \mathrm{mol} / \mathrm{l}$, $\mathrm{p}=0.267)$ and 24 months $869 \pm 427 \mu \mathrm{mol} / \mathrm{l}(\mathrm{p}=0.311)$ (Figure $2 \mathrm{~A})$.

Mean daily Phe-Intake was calculated with $1542 \pm 1146 \mathrm{mg}$ per day at baseline. Six months after the intervention, the mean intake remained stable at $1435 \pm 1051 \mathrm{mg} /$ day $(p=0.91)$, followed by a decline to $1237 \pm 730 \mathrm{mg} /$ day after 12 months and $1316 \pm 462 \mathrm{mg} /$ day after 18 months. The difference to baseline was statistically significant for 12 months $(p=0.03)$, but not for 18 month's value $(p=0.11)$. At the final examination after 24 months daily Phe-Intake increased to $1725 \pm 1097 \mathrm{mg} /$ day back to initial values $(p=0.53)$ (Figure 2B).

Mean daily intake of natural protein at baseline was $32.3 \pm 24.3 \mathrm{~g}$ per day. There was a significant decrease after 6 months $(26.9 \pm 18.8 \mathrm{~g} /$ day; $\mathrm{p}=0.049)$ and 12 months $(25.9 \pm 16.2 \mathrm{~g} /$ day; $\mathrm{p}=0.30)$ compared to baseline. Values at 18 months $(27.5 \pm 9.2 \mathrm{~g} /$ day; $p=0.26)$ and 24 months $(35.0 \pm 22.3 \mathrm{~g} /$ day; $p=0.87)$ did not differ to baseline (Figure 2C).

Mean daily supplementation of Phe-free amino acids at baseline was $26.2 \pm 19.2 \mathrm{~g}$ per day. In all follow-up examinations a significant increase compared to baseline values was calculated. In detail $42.4 \pm 17.6$ $\mathrm{g} /$ day after 6 moths $(\mathrm{p}=0.028), 52.1 \pm 29.9 \mathrm{~g} /$ day after 12 months $(\mathrm{p}=<0.01), 38.7 \pm 20.3 \mathrm{~g} /$ day after 18 months $(p<0.01)$ and $39.3 \pm 21.9 \mathrm{~g} /$ day after 24 months $(p=0.014)$ (Figure 2D).

At baseline, mean total protein intake (natural protein plus supplements) was $0.97 \pm 0.42 \mathrm{~g}$ per kg body weight $(\mathrm{g} / \mathrm{kgBW})$. After 6 months, the total protein intake increased to $1.1 \pm 0.33 \mathrm{~g} / \mathrm{kgBW}(p=0.041)$, which remained stable after 12 months $(1.1 \pm 0.34 \mathrm{~g} / \mathrm{kgBW} ; p=0.024)$ and 18 months $(1.0 \pm 0.24 \mathrm{~g} / \mathrm{kgBW}$ $\mathrm{p}=0.044)$. Even after 24 months the protein intake was significantly higher compared to baseline $(1.23 \pm 0.33 \mathrm{~g} / \mathrm{kgKB} ; \mathrm{p}=0.013)$ (Figure 3).

\section{Vitamins and micronutrients}

Concerning Vitamins and micronutrients, no significant changes were found after 24 months for Vitamin A $(1.7 \pm 0.4$ vs. $1.8 \pm 0.3 \mu \mathrm{g} / \mathrm{ml} ; \mathrm{p}=0.70)$, Vitamin C (15.1 \pm 5.3 vs. $12.4 \pm 4.5 \mathrm{mg} / \mathrm{l} ; \mathrm{p}=0.54)$, Vitamin $E$ 
(25.8 \pm 5.7 vs $28.4 \pm 9.9 \mu \mathrm{mol} / \mathrm{l} ; \mathrm{p}=0.18)$, plasma iron $(19.1 \pm 5.4$ vs. $20.8 \pm 7.7 \mu \mathrm{mol} / \mathrm{l} ; \mathrm{p}=0.20)$ and zinc (10.9 \pm 1.9 vs. $10.8 \pm 1.9 \mu \mathrm{mol} / \mathrm{l} ; \mathrm{p}=0.89$ ).

At baseline examination 3 patients (14\%) presented with lack of Vitamin B12 supply $(<191 \mathrm{pg} / \mathrm{ml})$ and 7 patients $(33 \%)$ with lack of Vitamin D $(<20 \mathrm{ng} / \mathrm{ml})$. At the final examination after 24 months, plasma Vitamin B12 increased to $424.8 \pm 176.9 \mathrm{pg} / \mathrm{ml}$ (baseline $368.6 \pm 205.6 \mathrm{pg} / \mathrm{ml} ; \mathrm{p}=0.049)$ ), all patients $(100 \%)$ had values upon the lower reference levels. Plasma Vitamin D increased to $30.4 \pm 9.9 \mathrm{ng} / \mathrm{ml}$ (baseline $24.5 \pm 10.1 \mathrm{ng} / \mathrm{ml} ; \mathrm{p}=0.06)$, only one patient (5\%) had apparent lack of Vitamin D. All values are presented in figure 4.

\section{Changes in body weight and BMI}

Mean body weight did not significantly change during the follow-up period $(65.5 \pm 22.0$ vs. $66.9 \pm 19.4 \mathrm{~kg}$; $\mathrm{p}=0.49$ ) as well as the body-mass index (BMl; $23.3 \pm 4.9 \mathrm{vs.} 23.4 \pm 4.3 \mathrm{~kg} / \mathrm{m} 2 ; \mathrm{p}=0.15$ ).

\section{Discussion}

According to well-known effects of strict diet in PKU, our study shows a reduction in Phe-levels and reduced amount of intake of natural protein within 6 months in adolescents and young adults with PKU. But in contrast to generally supposed ongoing effects of counselling by a professional nutrionist, we could clearly show the low half-life of specific changes in nutrition and health behavior after single interventions. After 12 months, plasma Phe-levels and protein intake are back to initial values and remain stable for the rest of the observation period. One aspect is certainly the management of PKU in Europe for the last decade, which permitted the loose permissive value of plasma Phe levels of $1200 \mu \mathrm{mol} / \mathrm{I}$. Another aspect is the low burden of disease in most adult patients, most of which would not consider themselves as patients with an inborn error of metabolism. This is based on the low predictive power of blood phenylalanine on the clinical outcome from the second decade of life onwards. [[i]] There is clear evidence for improved quality of life in patients with relaxation of their Phe-restricted diet. [[ii], [iii], [iv]] Conversely, establishing dietary limitations results in restrictions of daily life, which are not easy to accept in a cohort of patients with a desire to mobility and liberal lifestyle. Additionally, the long-term benefit of lower Phe-levels for the individual patient is not predictable. [17] Detailed cognitive testing and an assessment of quality of life in long-term follow-ups are needed to answer the question if life-long blood Phe control is able to prevent or improve cognitive impairment. Little harmful treatments as Saproterine $[8,[v],[v i]]$ are not applicable to the patients in this study.

In contrast to that, easy applicable therapeutic recommendations, as additional intake of amino acid supplement, are well tolerated and result in strict therapy adherence up to 24 months. Therefore, it was possible to reach the recommended intake of $1.2 \mathrm{~g} / \mathrm{kgBW}$ of protein per day and keep it over the 
observational period. Additional intake of Phe-free amino acids despite of missing dietary adherence did not lead to an increase of body weight in the study population within two years.

Especially in this vulnerable cohort of patients, additionally treatment options as Pegvaliase are most welcome. Therefore, a detailed information should be given to every single patient concerning new therapeutic options and potential side effects. Further studies are necessary for finding reliable recommendations for a treatment, resulting in severe adverse events in $10 \%$ of the treated patients [[vii]]. The available cognitive data for admission of the treatment [10, [viii], [ix], [x]] are based on depression and activity rating scalers, but neglect an persisting central executive impairment even in patients with well treated PKU and low blood Phe-levels [[xi]] which needs to be analyzed in further studies.

Another clear result of this study is, that lack of Vitamin B12 and Vitamin D, despite of being welldescribed in literature for years, still are common in PKU patients. In contrast to other reports [[xii]], the lack of vitamins not necessarily need to be substituted, but can effectively be equalized by a wellbalanced diet within 24 months. For other tested vitamins and micronutrients, no relevant aberrations were found.

The positive effects of counselling by a professional nutrionist recreate disease consciousness, focuses on diet by preparing a nutrition protocol and activates recourses for therapy and diet-adherence. The short half-life of this positive effects should result in frequent repetitions of nutritional counseling and consideration of new therapeutic options, especially in young adults.

\section{Conclusions}

Counselling by a professional nutrionist in young adults with PKU has clear short-term effects on plasma Phe-levels and health behaviour. Though, we could clearly show a low half-life of specific changes in nutrition and health behavior after single interventions of about 6 months. Thus, we recommend more frequent nutritional counselling, i.e. at least two times per year, to preserve positive effects on Phe-levels.

Easy applicable therapeutic recommendations, as additional intake of amino acid supplement, are well tolerated and result in strict therapy adherence up to 24 months. Therefore, it was possible to reach the recommended intake of $1.2 \mathrm{~g} / \mathrm{kgBW}$ of protein per day and keep it over the observational period. Additional intake of Phe-free amino acids despite of missing dietary adherence did not lead to an increase of body weight in the study population within two years. Lack of Vitamin B12 and Vitamin D still are common in PKU patients, but not necessarily need to be substituted. They can effectively be equalized by a well-balanced diet within 24 months.

\section{Limitations}


The small sample size impedes greater validity. Due to the rare condition of the disorder, randomized controlled trials are difficult to realize and result in reduced sample size. A long-term follow-up is needed to analyze the described effects after a longer period of time.

\section{Declarations}

\section{Ethics approval and Consent to Participate}

Positive ethical statement was obtained from the Ethics Committee (University of Ulm). All procedures followed were in accordance with the ethical standards of the responsible committee on human experimentation (institutional and national) and with the Helsinki Declaration of 1975, as revised in 2000. Informed consent was obtained from all patients for being included in the study.

\section{Consent for publication}

Informed consent for publication was obtained from all patients for being included in the study.

\section{Availability of data and material}

Original data is available upon personal request

\section{Competing interests}

Johannes Krämer declares that he has no conflict of interest.

\section{Funding}

Research funding was provided by Dr. Schaer AG/Spa, Zona di Produzione Winkelau 9, 39014 Postal (BZ), Italy.

\section{Authors' contributions}

Johannes Krämer: first draft, concept of the manuscript, data interpretation, statistical analysis, 
Acknowledgements

We thank all of our patients for participating in this study. Special thanks to Ms. Ursula Strittmatter, Sandra Manz, Yvonne Gernhardt and Elke Sandner for supporting the scientific work during daily routine.

\section{References}

1. Blau, van Spronsen FJ, Levy HL. Phenylketonuria. Lancet. 2010;376:1417-1427.

2. Bilder DA, Noel JK, Baker ER et al. Systematic review and meta-analysis of neuropsychiatric symptoms and executive functioning in adults with phenylketonuria. Dev Neuropsychol. 2016;41: 245-260.

3. Bilder DA, Kobori JA, Cohen-Pfeffer JL, et al.,Neuropsychiatric comorbidities in adults with phenylketonuria: a retrospective cohort study. Mol Genet Metab. 2017;121:1-8.

4. Jaulent P, Charriere S, Feillet F, Douillard C, Fouilhoux A, Thobois S. Neurological Manifestations in Adults with Phenylketonuria: New Cases and Review of the Literature. J Neurol. 2019; epub ahead of print. DOI: 10.1007/s00415-019-09608-2

5. van Spronsen FJ, van Wegberg AMJ, Ahring K et al. Key European guidelines for the diagnosis and management of patients with phenylketonuria. Lancet Diabetes Endocrinol. 2017:5:743-756.

6. van Wegberg AMJ, MacDonald A, Ahring K, et al. The complete European guidelines on phenylketonuria: diagnosis and treatment, Orphanet J Rare Dis. 2017;12:162.

7. Fiege $\mathrm{B}, \mathrm{Blau} \mathrm{N}$. Assessment of tetrahydrobiopterin (BH4) responsiveness in phenylketonuria, $\mathrm{J}$ Pediatr. 2017;150:627-630.

8. Burton BK, Grange DK, Milanowski A et al. The response of patients with phenylketonuria and elevated serum phenylalanine to treatment with oral sapropterin dihydrochloride (6Rtetrahydrobiopterin): a phase II, multicentre, open- label, screening study, J Inherit Metab Dis. 2007;30:700-707.

9. BioMarin Pharmaceutical Inc. European Commission Approves Palynziq ${ }^{\circledR}$ (pegvaliase injection) for Treatment of Phenylketonuria (PKU) in Patients Aged 16 Years or Older. 2019 https://investors.biomarin.com/2019-05-06-European- Commission-Approves-Palynziq-R-pegvaliaseinjection-for-Treatment-of- Phenylketonuria-PKU-in-Patients-Aged-16-Years-or-Older , Accessed date: 01 Jan 2020.

10. Longo N, Harding CO, Burton BK et al. Phase 1 trial of subcutaneous rAvPAL- PEG in subjects with phenylketonuria. Lancet. 2014;384:37-44.

11. Scriver CR, Kaufmann S, Eisensmith RC, Woo SL. The hyperphenylalaninemias. In: Scriver RC, Beaudet AL, Sly WS, Valle D (eds). The Metabolic and Molecular Basis of Inherited Disease. McGrawHill: New York, NY, USA, 1998, pp 1015-1075. 
12. Mönch E, Link R. Diagnostik und Therapie bei angeborenen Stoffwechselstö rungen, 2nd edn. SPS Publications: Heilbronn, Germany, 2006.

13. 4 Deutsche Gesellschaft für Ernährung e.V.(DGE). Referenzwerte für die Naehrstoffzufuhr. UmschauBraus: Frankfurt am Main, Germany, 2000.

14. Robinson M, White FJ, Cleary MA, Wraith E, Lam WK, Walter JH. Increased risk of vitamin B12 deficiency in patients with phenylketonuria on an unrestricted or relaxed diet. J Pediatr 2000; 136: 545-547.

15. Hvas AM, Nexo E, Nielsen JB. Vitamin B12 and vitamin B6 supplementation is needed among adults with phenylketonuria (PKU). J Inherit Metab Dis 2006; 29: 47-53.

16. Walter JH. Vitamin B12 deficiency and phenylketonuria. Mol Genet Metab 2011; 104: Suppl: S52S54.

17. Leuzzi V, Chiarotti F, Nardecchia F, van Vliet D, van Spronsen FJ. Predictability and inconsistencies of cognitive outcome in patients with phenylketonuria and personalised therapy: the challenge for the future guidelines. J Med Genet. 2019. Epub DOI: 10.1136/jmedgenet-2019-106278.

18. Bosch AM, Burlina A, Cunningham A et al. Assessment of the impact of phenylketonuria and its treatment on quality of life of patients and parents from seven European countries. Orphanet J. Rare Dis. 2015;10:80.

19. Demirdas S, Maurice-Stam H, Boelen CC et al. Evaluation of quality of life in PKU before and after introducing tetrahydrobiopterin (BH4); a prospective multi- center cohort study. Mol. Genet. Metab. 2013;110:S49-S56.

20. Douglas TD, Ramakrishnan U, Kable JA, Singh RH. Longitudinal quality of life analysis in a phenylketonuria cohort provided sapropterin dihydrochloride. Health Qual Life Outcomes. 2013;11:218.

21. Leuret $\mathrm{O}$, Barth M, Kuster A et al. Efficacy and safety of BH4 before the age of 4 years in patients with mild phenylketonuria, J Inherit Metab Dis. 2012;35: 975-981.

22. Longo N, Arnold GL, Pridjian G et al. Long-term safety and efficacy of sapropterin: the PKUDOS registry experience. Mol Genet Metab. 2015;114: 557-563.

23. Thomas J, Levy H, Amato $S$ et al. Pegvaliase for the treatment of phenylketonuria: results of a longterm phase 3 clinical trial program (PRISM), Mol Genet Metab. 2018;124:27-38.

24. Thomas J, Levy H, Amato $S$ et al. Pegvaliase for the treatment of phenylketonuria: results of a longterm phase 3 clinical trial program (PRISM), Mol Genet Metab. 2018;124:27-38.

25. Longo N, Zori R, Wasserstein MP et al. Long-term safety and efficacy of pegvaliase for the treatment of phenylketonuria in adults: combined phase 2 outcomes through PAL-003 extension study, Orphanet J Rare Dis. 2018;13:108.

26. Harding CO, Amato RS, Stuy M, et al., Pegvaliase for the treatment of phenylketonuria: a pivotal, double-blind randomized discontinuation Phase 3 clinical trial. Mol Genet Metab. 2018;124:20-26. 
27. Canton M, Le Gall D, Feillet F, Bonnemains C and Roy A. Neuropsychological Profile of Children with Early and Continuously Treated Phenylketonuria: Systematic Review and Future Approaches. $\mathrm{J}$ of the Inernat Neuropsych Society. 2019;25:624-643.

28. Rohde $C$, von Teefelen-Heithoff A, Thiele AG et al. PKU patients on a relaxed diet may be at risk for micronutrient deficiencies. Eur J Clin Nutr. 2014:68:119-124.

\section{Tables}

\begin{tabular}{ll}
\hline & Study group $(\mathrm{n}=21)$ \\
\hline Female gender (n) & $8(38 \%)$ \\
Age (yrs) & $22.6 \pm 7.5$ \\
\hline Mean GPV & $0.9 \pm 2.0(0-5)$ \\
\hline GPV $\leq 2.7$ (classic) (n) & $17(80.1 \%)$ \\
\hline Height & $164 \pm 18$ \\
\hline Weight & $65.5 \pm 22.0$ \\
\hline BMI & $23.3 \pm 4.9$ \\
\hline Use of Kuvan ${ }^{\circledR}$ & $0(0 \%)$ \\
\hline Plasma Phe $(\mu m o l / l)$ & $957 \pm 389$ \\
\hline Phe within reference $<600 \mu m o l / l(n)$ & $4(19 \%)$ \\
\hline Phe intake (mg/day) & $1542 \pm 1146$ \\
\hline Natural protein intake (g/day) & $32.3 \pm 24.3$ \\
\hline Use of Amino acids $(\mathrm{n})$ & $16(76 \%)$ \\
\hline Amino acid supplement (g/day) & $26.2 \pm 19.2$ \\
\hline
\end{tabular}

Table 1. Baseline characteristics

\begin{tabular}{|c|c|c|c|c|c|c|}
\hline & Retrospective & Baseline & $\begin{array}{c}\text { Follow-Up } 1 \\
\text { (6 months) }\end{array}$ & $\begin{array}{r}\text { Follow-Up } 2 \\
\text { (12months) }\end{array}$ & $\begin{array}{r}\text { Follow-Up } 3 \\
\text { (18 months) }\end{array}$ & $\begin{array}{l}\text { Follow-Up } 4 \\
\text { (24 months) }\end{array}$ \\
\hline Plasma Phe $(\mu \mathrm{mol} / \mathrm{l})$ & $930 \pm 414$ & $926 \pm 432$ & $709 \pm 314^{* \#}$ & $901 \pm 398 *$ & $919 \pm 306$ & $869 \pm 427$ \\
\hline Phe within reference <600 $\mathrm{mmol} / \mathrm{l}(\mathrm{n})$ & $4(19 \%)$ & $4(19 \%)$ & $8(38 \%)^{* \#}$ & $5(24 \%)^{*}$ & $7(33 \%)$ & $6(29 \%)$ \\
\hline Phe intake (mg/day) & $1530 \pm 1139$ & $1542 \pm 1146$ & $1435 \pm 1051$ & $1237 \pm 730^{\#}$ & $1316 \pm 462$ & $1725 \pm 1097$ \\
\hline Natural protein intake (g/day) & $33.4 \pm 26.1$ & $32.3 \pm 24.3$ & $26.9 \pm 18.8^{* \#}$ & $25.9 \pm 16.2^{\#}$ & $27.5 \pm 9.2$ & $35.0 \pm 22.3$ \\
\hline Use of Amino acid mixture (AAM)(n) & $16(76 \%)$ & $16(76 \%)$ & $21(100 \%)$ & $20(95 \%)$ & $19(90 \%)$ & $20(95 \%)$ \\
\hline Total supplemental protein intake ( $\mathrm{g} /$ day) & $23 \pm 15$ & $26.2 \pm 19.2$ & $42.4 \pm 17.6^{* \#}$ & $52.1 \pm 29.9^{\#}$ & $38.7 \pm 20.3_{\#}$ & $39.3 \pm 21.9^{\#}$ \\
\hline Total protein intake (g/kgBW) & $0.99 \pm 0.38$ & $0.97 \pm 0.42$ & $1.1 \pm 0.33^{* \#}$ & $1.1 \pm 0.34^{\#}$ & $1.0 \pm 0.24 \#$ & $1.23 \pm 0.33^{\#}$ \\
\hline Vitamin A ( $\mu \mathrm{g} / \mathrm{ml})$ & - & $1.7 \pm 0.4$ & - & - & - & $1.8 \pm 0.3$ \\
\hline Vitamin B12 (pg/ml) & - & $368.6 \pm 205.6$ & - & - & - & $424.8 \pm 176.9^{\#}$ \\
\hline Vitamin C (mg/l) & - & $15.1 \pm 5.3$ & - & - & - & $12.4 \pm 4.5$ \\
\hline Vitamin D (ng/ml) & - & $24.5 \pm 10.1$ & - & - & - & $30.4 \pm 9.9^{\#}$ \\
\hline Vitamin $E(\mu m o l / l)$ & - & $25.8 \pm 5.7$ & - & - & - & $28.4 \pm 9.9$ \\
\hline Plasma iron $(\mu \mathrm{mol} / \mathrm{l})$ & - & $19.1 \pm 5.4$ & - & - & - & $20.8 \pm 7.7$ \\
\hline Zinc $(\mu \mathrm{mol} / \mathrm{l})$ & - & $10.9 \pm 1.9$ & - & - & - & $10.8 \pm 1.9$ \\
\hline
\end{tabular}

Table 2. Overview of Phe-levels, Vitamins and micronutrients in plasma as well as data out of 3-day protocols to all examination points.

* p-value $<0.05$ compared to baseline; \# p-value $<0.05$ compared to previous visit

AAM, amino acid mixture; BW, body weight; g, gram; kg, kilogram, Phe, phenylalanine. 
Figures

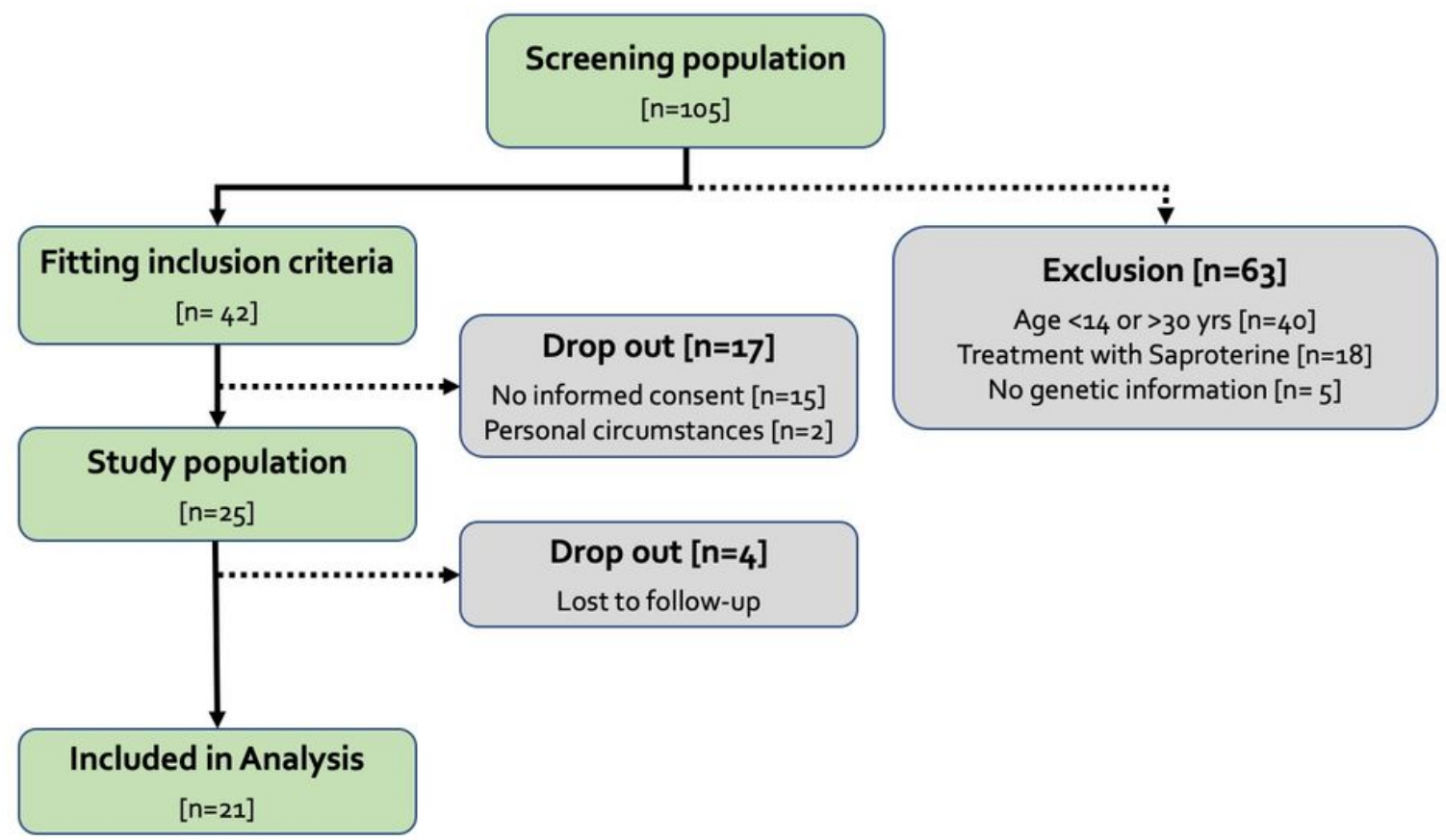

\section{Figure 1}

Study design 

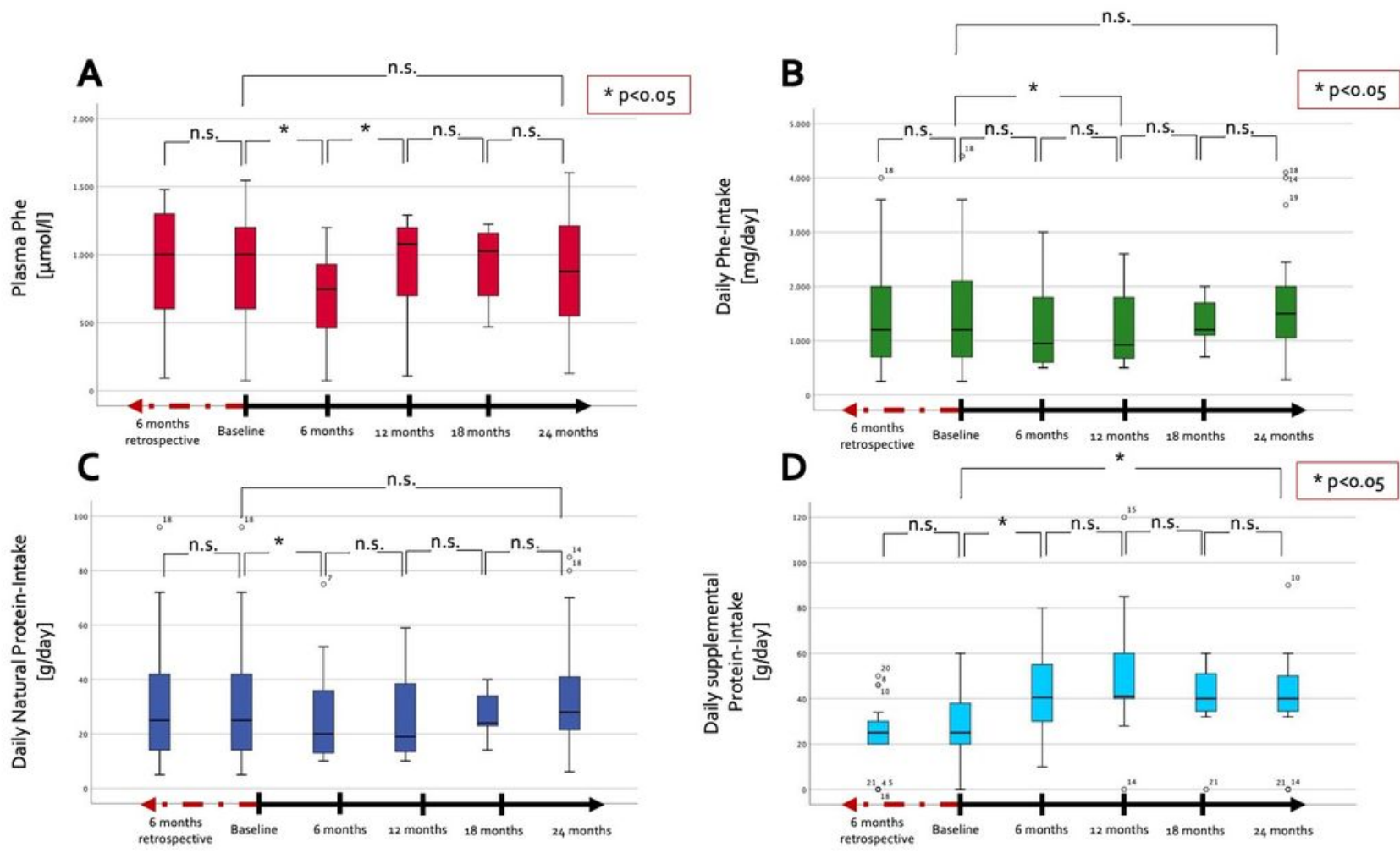

Figure 2

Box plots Plasma Phe levels and daily protein intake A. Plasma Phe-levels $(\mu \mathrm{mol} / \mathrm{l})$ baseline vs. follow-up examinations. B. Daily Phe-intake (mg/day) baseline vs. follow-up examinations. C. Daily natural protein intake (g/day) baseline vs. follow-up examinations. D. Daily supplemental protein intake baseline vs. follow-up examinations. Significant differences are marked with stars as mentioned in the figure. 

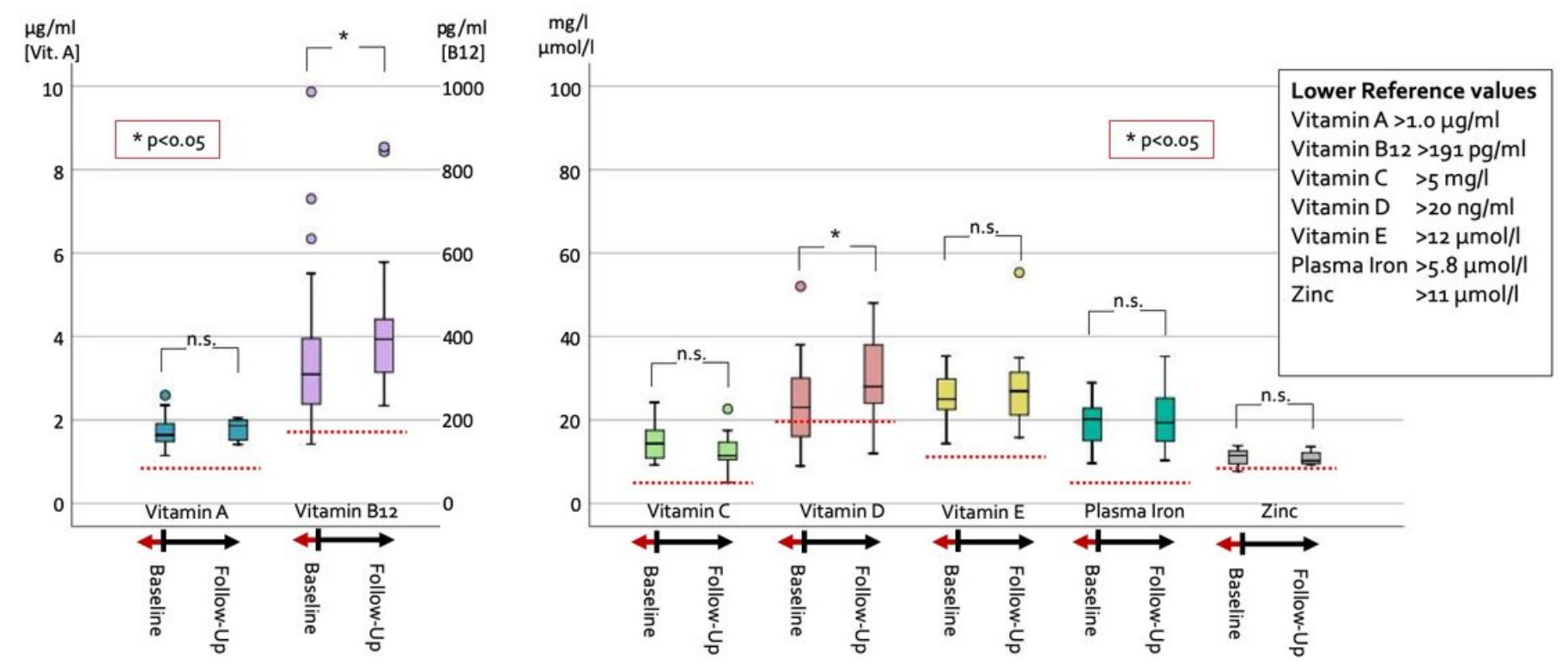

\section{Figure 3}

Box plots micronutrients and Vitamins Box plots of Vitamins and micronutrients baseline vs. final followup examination (24 months). Left box baseline, right box follow-up. Lower reference values are marked with red dotted line, respectively. Significant differences are marked with stars as mentioned in the figure. 


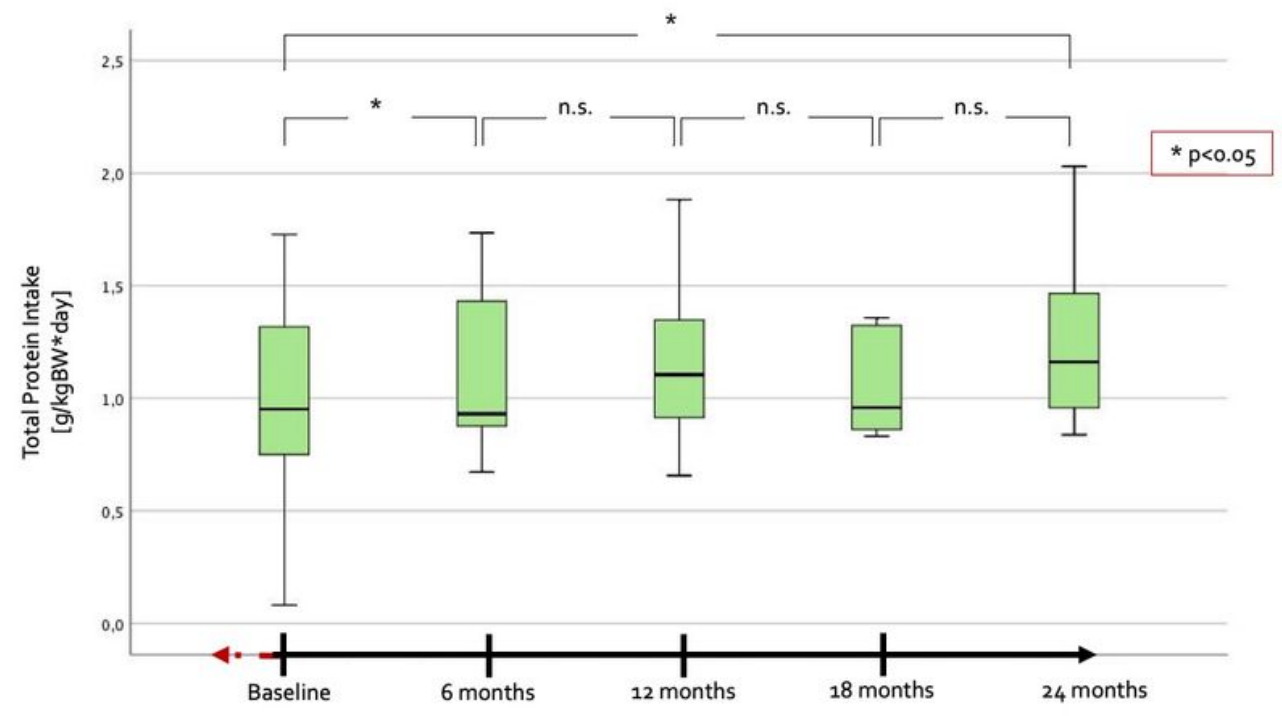

\section{Figure 4}

Box plots total daily protein intake Total Daily Phe-intake (natural plus supplemental protein) (mg/day) baseline vs. follow-up examinations. Significant differences are marked with stars as mentioned in the figure. 